\title{
Strategic management applied to the Six-Sigma suitability appraisal for R\&D in FMCG companies
}

\author{
Gestão estratégica aplicada à avaliação da adequação do Six-Sigma para P\&D em \\ empresas de bens de consumo
}

\author{
Davidson Lütkenhaus ${ }^{1 *}$; Marcella Nunes de Freitas ${ }^{2}$ \\ 1 Procter \& Gamble - Research Engineer - Home Care Product and Process Engineering - Address: \\ Temselaan 100 - B-1853 - Strombeek-Bever, Belgium \\ 2 Escola Superior de Agricultura “Luiz Queiroz"/USP. Doutoranda em Fitotecnia. - Av. Pádua Dias, 11 - CEP \\ 13418-900 - Piracicaba (SP), Brasil
}

\begin{abstract}
This research assesses the suitability of the Six-sigma program for R\&D in FMCG companies. The study also includes an analysis of its potential advantages and challenges for this business area. This was performed through data acquisition using a web-based survey targeting large scale multinational companies. Results showed that most R\&D personnel within FMCG companies see Six-sigma as a positive methodology for their sector. Roughly $80 \%$ of the participants selected time saving and better knowledge allocation as the main advantages of the Six-sigma system. Almost $90 \%$ of the survey contributors believe that the series of potential benefits could lead to important scientific breakthroughs. A financial challenge is expected with the implementation and it was said to be the main concern of R\&D personnel, especially from those with managerial backgrounds. Cultural changes and scientific obstacles were not reported as imminent threats to the new system. In light of the above, Six-sigma was found to be suitable for R\&D in FMCG companies requiring only a few modifications in its standards and a well-defined strategic implementation plan.
\end{abstract}

Keywords: Fast Moving Consumer Goods, DMAIC, Technology Management, Total Quality Management

\section{Resumo}

Esta pesquisa avalia a adequação do programa Six-Sigma para o setor de $P \& D$ em empresas de bens de consumo. O estudo também inclui uma análise das vantagens potenciais e dos desafios para esta área de negócio. Este estudo foi realizado por meio da aquisição de dados, utilizando um questionário online direcionado à profissionais de grandes empresas multinacionais. Os resultados mostraram que a maior parte dos profissionais de P\&D nas empresas de FMCG veem o Six-Sigma como uma metodologia positiva para este setor. Cerca de $80 \%$ dos participantes selecionados apontam a economia de tempo e a melhor alocação de conhecimento como as principais vantagens do sistema Six-sigma. Quase $90 \%$ dos colaboradores da pesquisa acreditam que a série de benefícios potenciais podem levar a descobertas científicas importantes. Um desafio financeiro é esperado com a implementação, sendo a principal preocupação dos profissionais de $P \& D$ que responderam o questionário, especialmente daqueles com cargos gerenciais. Mudanças culturais e obstáculos científicos não foram relatados como ameaças eminentes para o novo sistema. Portanto, o Six-Sigma foi apontado como um sistema adequado para $P \& D$ em empresas de bens de consumo, exigindo para tal implementação apenas algumas modificações em suas normas e um plano de estratégico bem definido.

Palavras-chave: Bens de Consumo, Gestão de qualidade Total, DMAIC, Gestão de Tecnologia

\footnotetext{
1 * Corresponding author: <lutkenhaus.dl@pg.com> Received: February 29, 2016 Accepted: April 02, 2016
} 


\section{Introduction}

The Fast Moving Consumer Goods (FMCG) industry focuses on the manufacturing of everyday consumer products such as foods, cosmetics, detergents, and household cleaners. As these goods are essential for daily activities, FMCG market will always have consumers. On the other hand, it is a very competitive business area because it involves constant product development to meet the consumer's expectations (Hamister, 2007; Thain; Bradley, 2014).

FMCG is, by its very nature, a fast-moving business which depends primarily on research e development $(R \& D)$ to keep up with the dynamic global market. Research and Development professionals are the people who take marketing ideas and turn them into new products. They ensure that FMCG businesses remain competitive.

Effective R\&D must be driven very strategically in order to manage the research complexity in the current market. The complexity of the R\&D sector arises from its three main stages: project portfolio, R\&D structural organization, and innovation management (Akhilesh, 2014). The presence of complexity in one of these areas promotes innovation delays and may cause time and resources wastage.

The attainability of six sigma program is evaluated in this paper in order to optimize the R\&D process and ensure that it will be efficient to keep up with this fastpaced market. Six-sigma is a methodology developed to ensure process improvement and consistent output by identifying the causes of deviations and/or defects and removing them. It is traditionally applied to manufacturing processes but more recently is being used in several business areas.

FMCG industry, also known in some regions as CPG (Consumer packaged goods) industry, primarily deals with the production, distribution, and marketing of consumer goods (Thain; Bradley, 2014). These consist of consumables which are normally purchased by the consumers at a regular interval.

The foundation of the FMCG business is focused on constructing renowned brands and accomplishing large distributions levels. The main companies in this sector choose to promote globally their biggest brands, albeit maintaining small brands to fulfill specific needs of local markets. Cooperation among suppliers, manufacturers, logistics, and distributors is crucial for a smooth operation of the supply chain because many fast moving consumer goods have short shelf-life (Hamister, 2007).

Several FMCG companies invest a lot of money in market research, $R \& D$, and product positioning in order to go along with the fast-paced advances in this sector 
(Dogra; Ghuman, 2010). Advertisements are highly significant to drive brand awareness and enlarge the segment (Jaray, 2005).

Effective R\&D in FMCG is driven not only by a marketing strategy to acquire consumer insight but also by technical team formed of scientists and engineers. It is complex business which crosslinks a variety of expertise. This is necessary to maintain the business always a step ahead of its competition (Hamister, 2007; Thain; Bradley, 2014).

Six-sigma is a quality and efficiency methodology which applies statistical tools in order decrease variations in business and industrial processes by eliminating defects, minimizing wastage, optimizing time, boosting productivity, and reducing costs (Mccarty et al., 2004; Hemant, 2010; Evans; Lindsay, 2014). The Six Sigma program was developed by Motorola as a set of managerial and statistical tools introduced by William Smith in the mid-1980s (Taghizadegan, 2010; Tavana, 2014).

The foundation of the name comes from the Greek letter "sigma" $(\sigma)$ which is used in statistics to represent standard deviations. The term Six-Sigma originally arose from the manufacturing sector where it represents a process in which $99.99966 \%$ of all means to produce a part are expected to be defect-free, i.e., only 3.4 defects per million units manufactured (Hill; Jones, 2009).

The Six-sigma implementation is typically achieved by using management by process (Figure 1). Its application involves the establishment of a coherent path of process steps to reach the aimed results (Barone; Lo Franco, 2012).

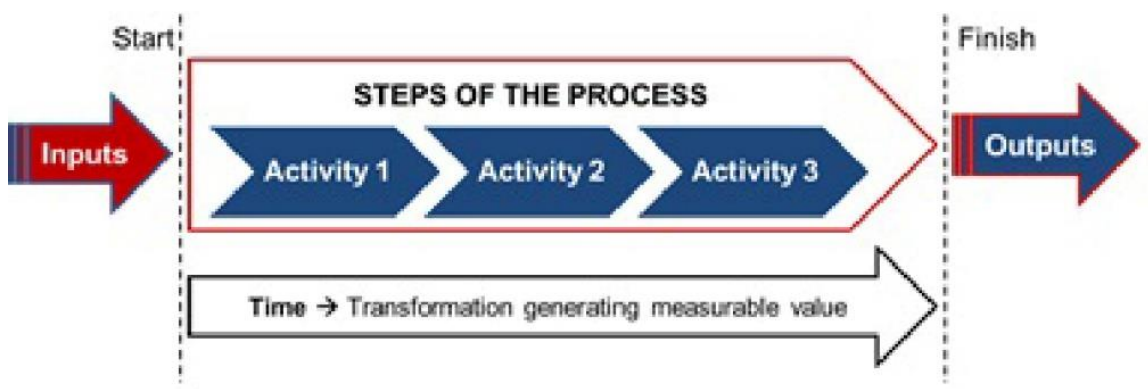

Figure 1. Generic representation of the process concept

Source: Barone and Lo Franco (2012) adapted

It can be seen that a process presents well defined starting and finishing points. Also, inputs and outputs must be measurable so the value generated during the process can be assessed. The order of the activities must be established although they can also 
run in parallel (Barone; Lo Franco, 2012). Managing a business by process facilitates problem identification and elimination.

Six-Sigma system is directly linked to the fundamental aspects of Total Quality Management (TQM) and Shewhart's statistical process control. One of the main methodologies used in Six Sigma is called DMAIC process, which stands for Define, Measure, Analyze, Improve, and Control (Figure 2) (Creveling, 2002).

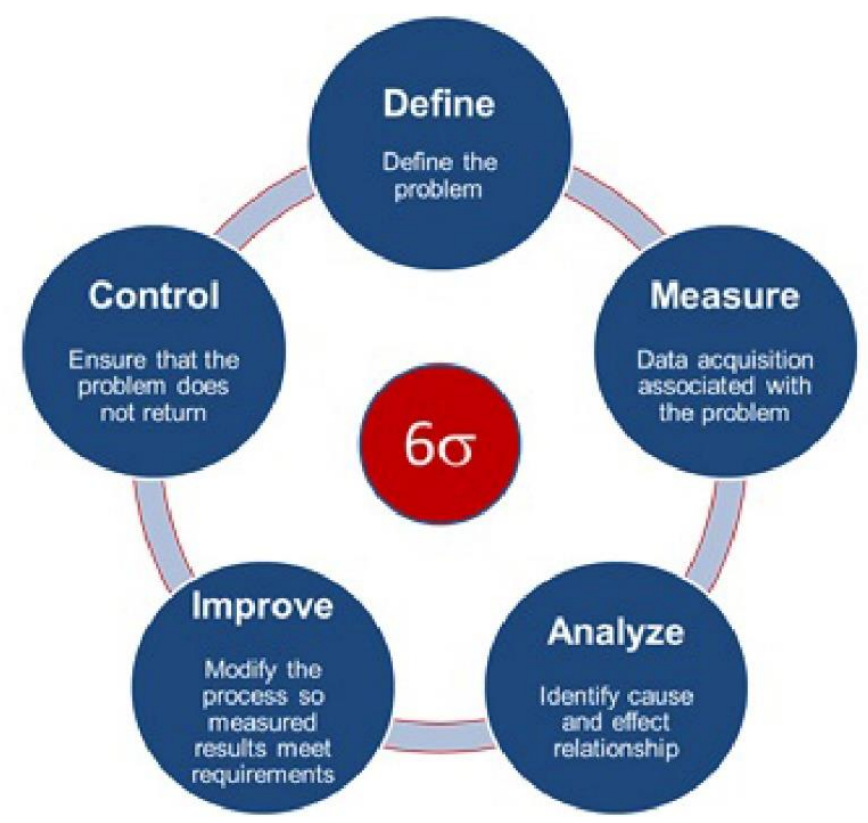

Figure 2. Steps of the Define, Measure, Analyze, Improve and Control - DMAIC method Source: Creveling (2002)adapted

The DMAIC process starts with the problem definition and it is followed by the measurement of data that are relevant to the problem solving step. Then these data are analyzed and the key variables influencing the process are established. During the improvement phase the problem is eliminated with the fulfillment of all process requirements. Finally, the control step is employed in order to guarantee that the problem will not reoccur (Creveling, 2002).

Reports of Six-sigma for the R\&D sector show that for early stage research projects the process is based on ways of identifying key product properties, measuring these properties, and the establishing specifications and goals (Joglekar, 2003).

The implantation of Six-sigma for R\&D is a controversial topic with some arguing that could restrict innovation and others advocating exactly the opposite.

This study assesses the implementation viability of the Six-Sigma program for $R \& D$ in FMCG companies. The evaluation also includes an analysis of the potential 
advantages generated by the six sigma system for R\&D as well as its limitations for this business field.

\section{Materials and methods}

Survey was adopted as the data acquisition method for this research which investigated the main advantages and challenges for implementing Six-sigma for $R \& D$ in FMCG companies through the questionnaire shown in Appendix 1.

The population for this survey consisted of $R \& D$ professionals working on either managerial or technical positions within major Fast Moving Consumer Goods companies in central Europe and the UK. The survey targeted large scale multinational companies listed in Table 1. They represent a population of roughly 4000 FMCG R\&D professionals in this region (Nestlé, 2014; Unilever, 2014; P\&G, 2015). Small or medium size companies were not included in the population once they invest none or little resources in research and development.

Table 1. Fast Moving Consumer Goods - FMCG research centers targeted for the Sixsigma survey

\begin{tabular}{ll}
\hline Company & Location \\
\hline Procter \& Gamble & Brussels, Belgium \\
Unilever & Port Sunlight, United Kingdom \\
Nestle & Lausanne, Switzerland \\
\hline
\end{tabular}

The sample size was calculated using Slovin's formula (Eq. 1) (Subong, 2005; Ryan, 2013). The results were obtained considering a confidence level of $90 \%$ which gives a margin of error of 0.1 .

$$
n_{\text {sample }}=\frac{N_{\text {population }}}{\left(1+N_{\text {population }} e_{\text {margin }}^{2}\right)}
$$

Where ' $n$ ' is the necessary sample size, ' $N$ ' is the known population and ' $e$ ' is the margin of error. Considering the confidence level of $90 \%$, Slovin's equation gives a sample size of 97.56 . Thus the research needs at least 98 respondents to be statistically representative of the whole population within the given confidence interval. 
Data collection was performed using a web-based questionnaire tool. Data were used not only to get a numerical evaluation of suitability of Six-sigma program for R\&D but also to generate a SWOT diagram and obtain a qualitative overview of challenges and opportunities. A SWOT analysis evaluates the strengths, weaknesses, opportunities, and threats that are relevant to a company in a new marketing plan (Tuckwell, 2008). In this study, a SWOT chart was used to clarify these different aspects for the application of Six-sigma for R\&D. A final analysis correlating quantitative and qualitative data was done in order to assess the suitability of the Six-sigma program for $R \& D$ in FMCG companies.

\section{Results and discussion}

A total of 124 respondents were recruited during the data acquisition stage. This amount is greater than the 98 required for statistical significance of this study. Initial survey questions (1-4) were used to determine the profile of the selected population's sample. This includes their area of occupation, period of employment at the company, familiarity with Six-sigma fundamentals, and previous hands-on experience with the methodology. The remaining questions were used to determine the main advantages and challenges during Six-sigma implementation for R\&D in FMCG companies.

Questions 1 to 4 were designed to better understand the sample's profile. They are essential in order to analyze the responses of more specific questions regarding advantages and challenges of the Six-sigma implementation process.

Respondents were classified in two categories according to their areas of occupation: 1) technical, consisting of engineers, scientists, technicians, etc; and 2) managerial, formed of managers, supervisors, coordinators, directors, etc (Figure 3).

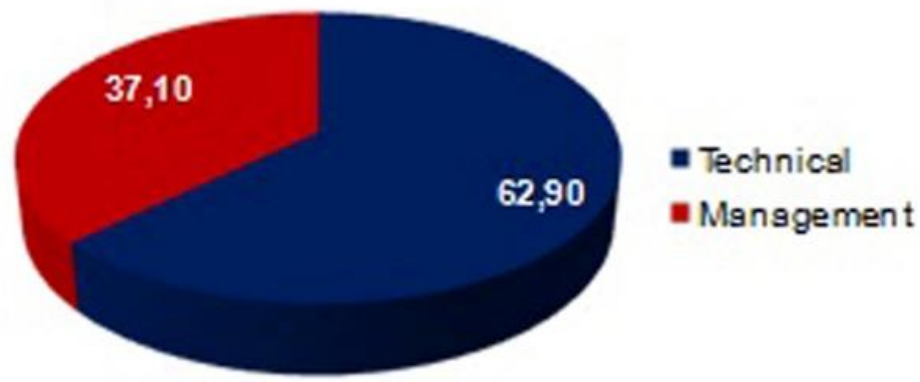

Figure 3. Sample classified according to their area of occupation 
It can be seen in Figure 3 that the majority of the respondents come from a technical background. This is in accordance with the reality in research and development sector of FMCG companies. A large number of scientific researchers and technical personnel are usually predominant over a smaller amount of managerial staff.

The second question was elaborated to evaluate the period that the respondents work for their companies (Figure 4). This enables to assess the depth of knowledge the population presents about the R\&D sector.

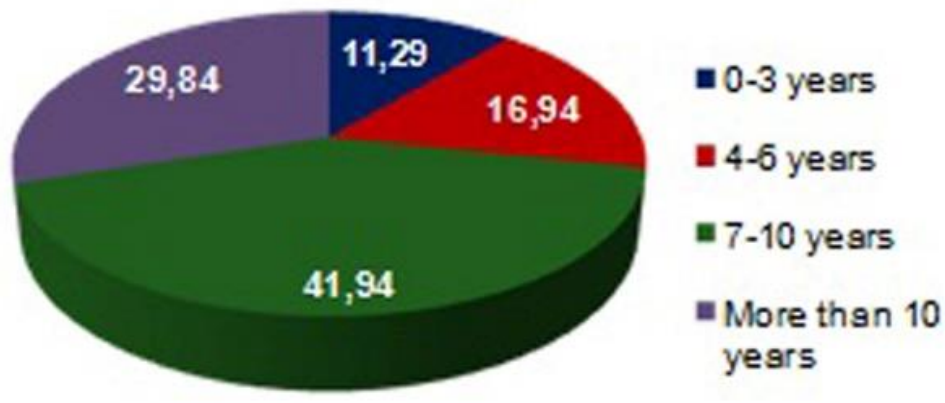

Figure 4. Period of employment in the company

One can see that more than $70 \%$ of the population has significant experience in R\&D with over 7 years of work experience in the same company. This brings a high credibility to their survey input since most of them are professionals with a broad knowledge in this industrial sector. Only approximately $11 \%$ of the respondents show less than 3 years of experience, but their responses are equally appreciated since they may bring a different or new perspective to the management system.

Question 3 aimed to assess the familiarity of the survey participant with Six-sigma tools (Figure 5).

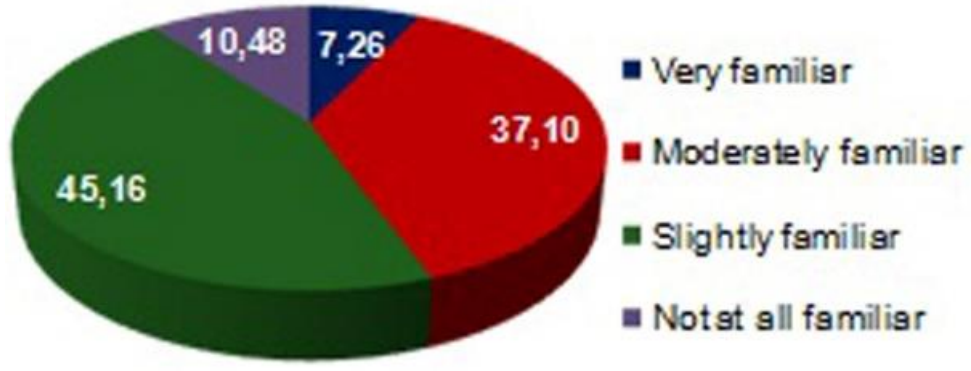

Figure 5. Familiarity of the respondents with Six-sigma system

According to data from Figure 5, the bulk of the population is slightly familiar with Six-sigma method, i.e. they have heard of it but they do not know many details about it. 
Another considerable amount of the participants (around 38\%) claim to have a moderate understanding of the program. This is important for the survey outcome since this fraction of the population sample presents knowledge of Six-sigma principles and their advantages. As expected just $7.26 \%$ of the participants claim to have a very deep understanding of Six-sigma, while $10.48 \%$ said to be unaware of it. The variety of the respondents' backgrounds is crucial for an impartial and more realistic survey analysis.

The final profiling question was related to the previous usage of the Six-sigma system in order to evaluate what percentage of the participants actually had hands-on experience with this method (Figure 6).

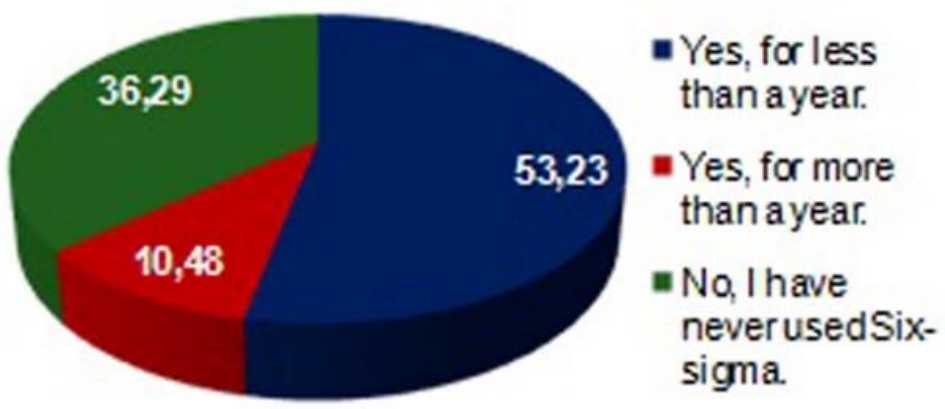

Figure 6. Previous experience using Six-sigma tools

It can be inferred from Figure 6 that a little over $50 \%$ of the respondents had already some experience using the Six-sigma program but for a period of time inferior to one year. These participants can thus provide very noteworthy insights to the survey since their hands-on experience helps to foresee the main challenges and advantages of the program for R\&D. Nearly $11 \%$ of the population sample said to have over a year experience with Six-sigma and the remaining of the respondents never used the statistical program. Thereby, the sample recruited for this research showed to be very diverse which is essential for a non-bias data acquisition. This is a testament of the impartial nature of the results presented in this study.

Question 5 was given aiming to obtain a general idea of how the participants perceive Six-sigma program and its suitability for $R \& D$ in consumer goods companies. This is a good indication of how people would feel with the implementation of the program and how keen they would be to embrace this change (Figure 7). 


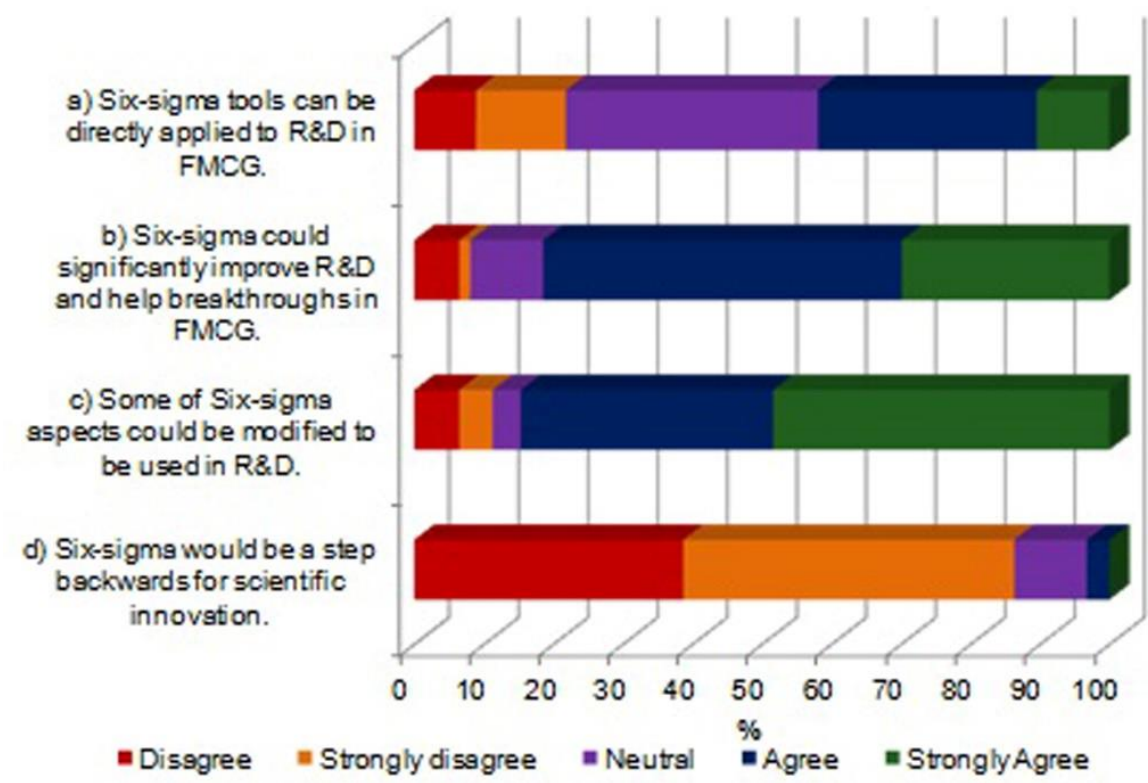

Figure7. Participants' agreement level to different Six-sigma scenarios within Research and Development - R\&D

It can be inferred from Figure 7 that a large amount of the respondents (nearly $37 \%$ chose the answer 'neutral') was unsure about the direct application of Six-sigma to R\&D. Furthermore, approximately $42 \%$ agrees (blue and green data combined) that the methodology could be directly applied as it is. This is a good indication that people tend to believe in the efficiency of Six-sigma to improve performance.

Over $80 \%$ of the participants feel that Six-sigma could boost significant breakthroughs in Fast Moving Consumer Goods companies. This is a highly positive aspect to support the methodology implementation. Similarly, around $84 \%$ of the investigated population sample believes that some aspects of the Six-sigma tools could be modified to better suit the R\&D sector. In light of the above, Six-sigma implementation would be advised after careful consideration of appropriate modifications for R\&D.

None of the survey contributors strongly agreed that Six-sigma would be a step backwards for innovation. On the contrary, the vast majority (about $86 \%$ ) of them disagreed with this affirmation. This clear trend comes to corroborate that Six-sigma could promote a positive change towards groundbreaking research processes.

A rating scale was also used to more clearly elucidate the responses trends for each of the proposed scenarios. An average distribution of the collected answers is given which summarizes them as a final score number (Figure 8). 


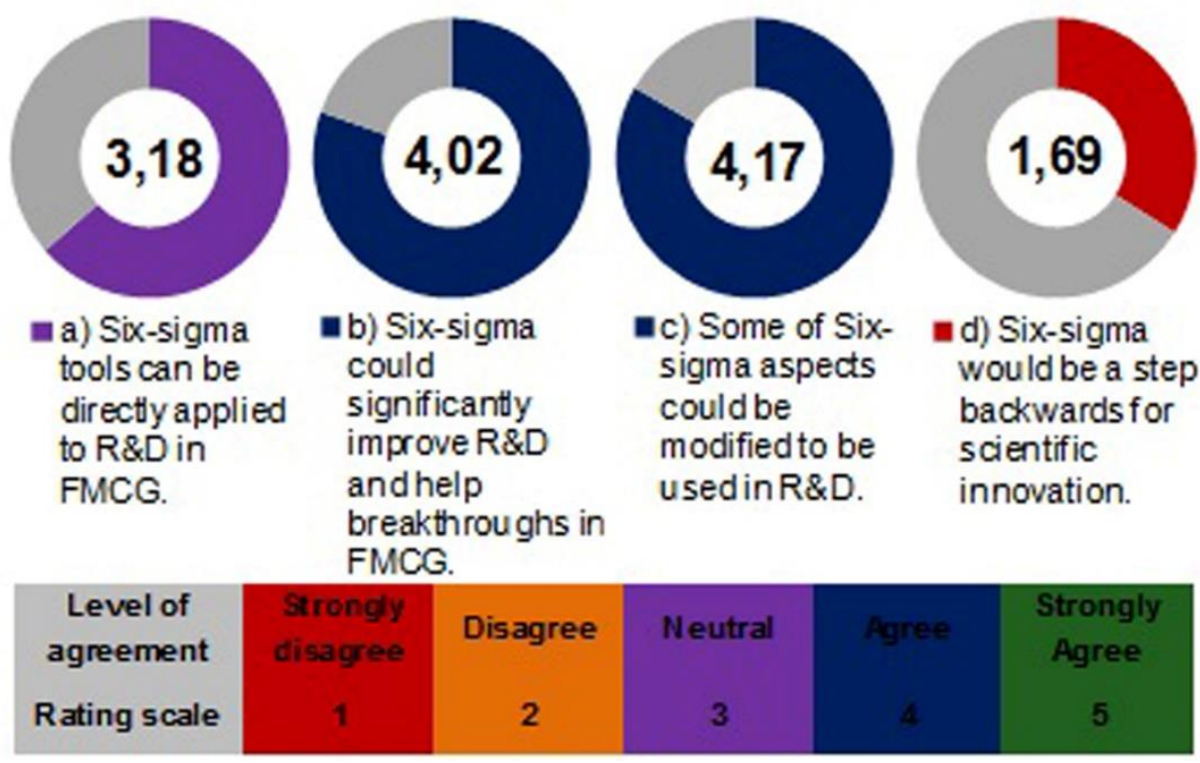

Figure 8. Rated average results for different Six-sigma scenarios

Averages shown in Figure 8 enable to better visualize people's responses according to the proposed rating scale. It is noted that people are neutral about a direct application of Six-sigma although they agree with the innovation potential of the program. They also concur that a few modifications are necessary to implement the program. This is accordance with the studies of Chakravort (2009) which reports the absence of a specific implementation plan as one of the major reasons for six sigma failure. Finally, it is notoriously seen that the majority of the respondents disagree that Six-sigma would be a drawback for FMCG.

Question 6 was employed in order to evaluate the likelihood of attaining some advantages, if any, with the implementation of Six-sigma (Figure 9). 


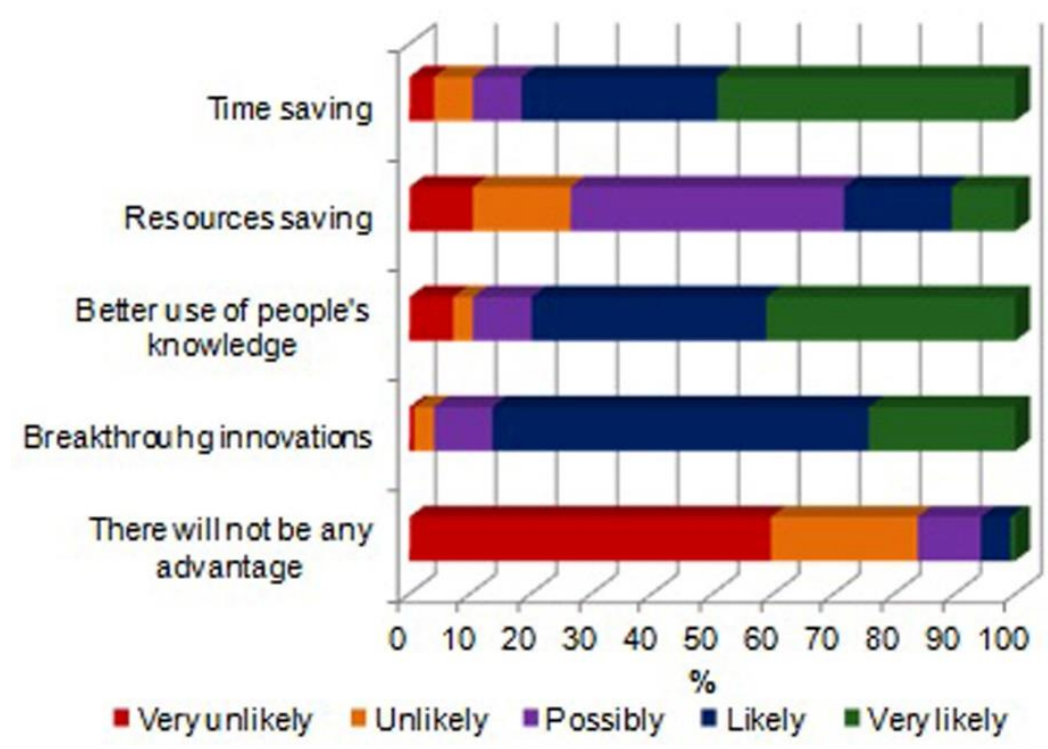

Figure 9. Likelihood of advantages with Six-sigma for Research and Development - R\&D

Nearly half of the participants think that time reduction in the research process is very likely and about $32 \%$ believe this is a likely advantage. This totalizes over $80 \%$ of the sample in accordance with the time-saving potential of the Six-sigma program.

The majority of the survey contributors said that breakthrough innovations and better allocation of right people for specific tasks would also be likely Six-sigma advantages. In both cases, roughly $80 \%$ of the respondents believed in a positive prospect for these benefits. Finally, approximately $84 \%$ of the people thinks that a scenario with no advantages would be unrealistic and only about $6 \%$ believe that this is a likely situation (Figure 9).

An apparent comprehension of the likelihood of each advantage can be seen through the individual average results shown in Figure 10.

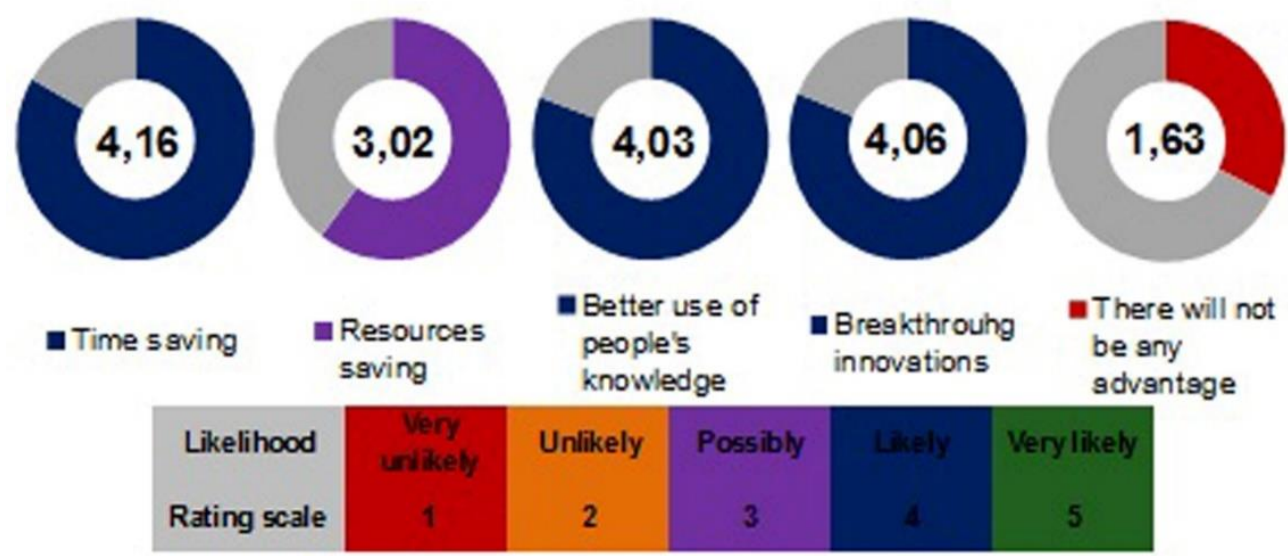

Figure 10. Average results for each advantage 
The average results clearly show that time-saving, better use of people's knowledge, and groundbreaking innovations are the main advantages likely to be attained with Six-sigma for R\&D. It is also noticed that people believe to be possible to obtain a reduction in resources wastage similarly to the results found in Kwak and Anbari's (2006) research, which shows that Six-sigma for R\&D could lead to a reduction of resources usage over time. Finally, one of the most important information presented in these results is the fact almost all participant disbelieve that there will not be any advantage with the Six-sigma program.

The results strongly suggest that R\&D in FMCG companies would benefit from the practice of the Six-sigma tools. This is in accordance with Brun's study which reports that the most successful implementations occur when they are extended to all company's processes and are not limited to production (Brun, 2011).

Although there are many advantages associated with Six-sigma for $R \& D$, many challenges could potentially arise with this implementation process. The assessment of these risks was performed based on the results acquired from question 7 of the survey (Figure 11).

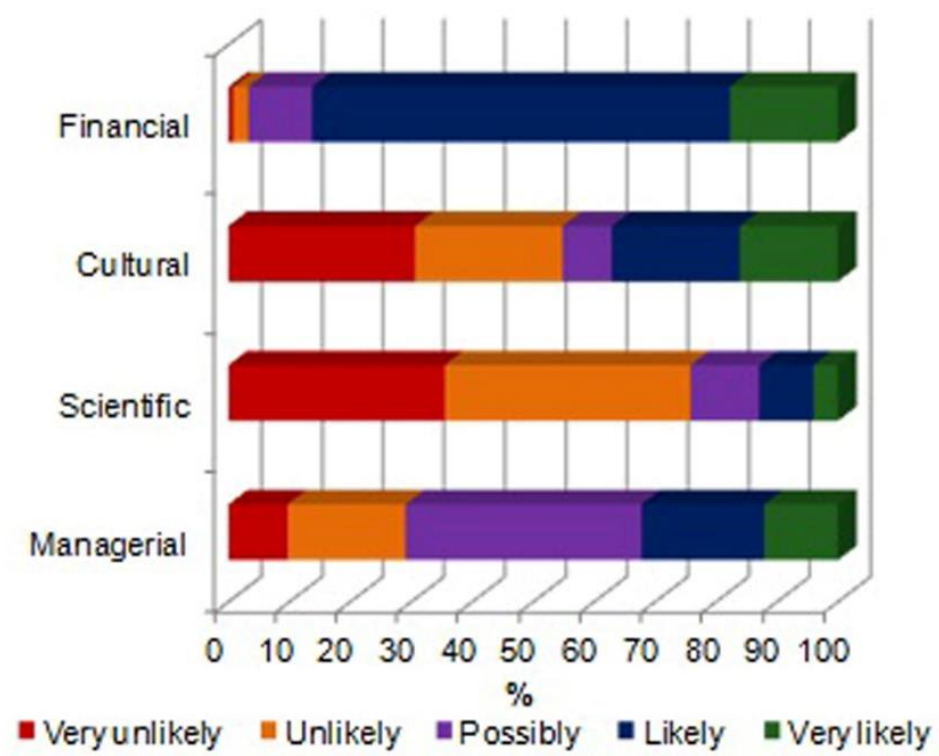

Figure 11. Likelihood of challenges associated with Six-sigma for Research and Development - R\&D

It is particularly observed that roughly $86 \%$ of participants think that a financial challenge will be faced during Six-sigma implementation (Figure 11). This is mainly associated with training costs in order to get people to understand and apply the program. All managerial respondents marked likely or very likely in this option of the 
questionnaire. Therefore, a well-structured strategic plan must be elaborated prior the implementation in order minimize costs and avoid unnecessary expenditures.

Over half of the population sample seems to be in accordance with the adoption of Six-sigma for R\&D since they see a cultural challenge as an unlike or very unlike problem during this process. Moreover, approximately $75 \%$ of them are not concerned with a reduction of the scientific innovation after the implementation. On the contrary, they believe that this step back is unlikely to occur (Figure 11).

When it comes to management changes for applying Six-sigma, the bulk of the sample (nearly $40 \%$ ) seems to believe they are possibly a challenge but not definitive concern (Figure 11). Most of the participants who selected 'likely' have a managerial background, while the $30 \%$ who chose 'unlikely' work predominantly in the technical area. This is a powerful indication that a strategic implementation will only be smooth and efficient when combining the needs of both areas (technical and managerial).

According to the research of Easton and Rosenzweig (2012), the team leader experience is a decisive factor for success or failure of the program, therefore the selection of the managers during the strategic changes is crucial for its success. Management participation and commitment was also listed by Ho and co-workers (2008) as one of the key success factors. The lack of an implementation model was reported by Chakravorty (2009) as one of the main reasons for the Six-sigma failures. This comes to reinforce the idea that a well-defined strategic plan must be performed in order to promote positive results.

The average results shown in Figure 12 are useful to clarify the main concerns during Six-sigma incorporation for R\&D in the consumer goods sector. The rating scale helps to understand the main problems seen by the research subject. 


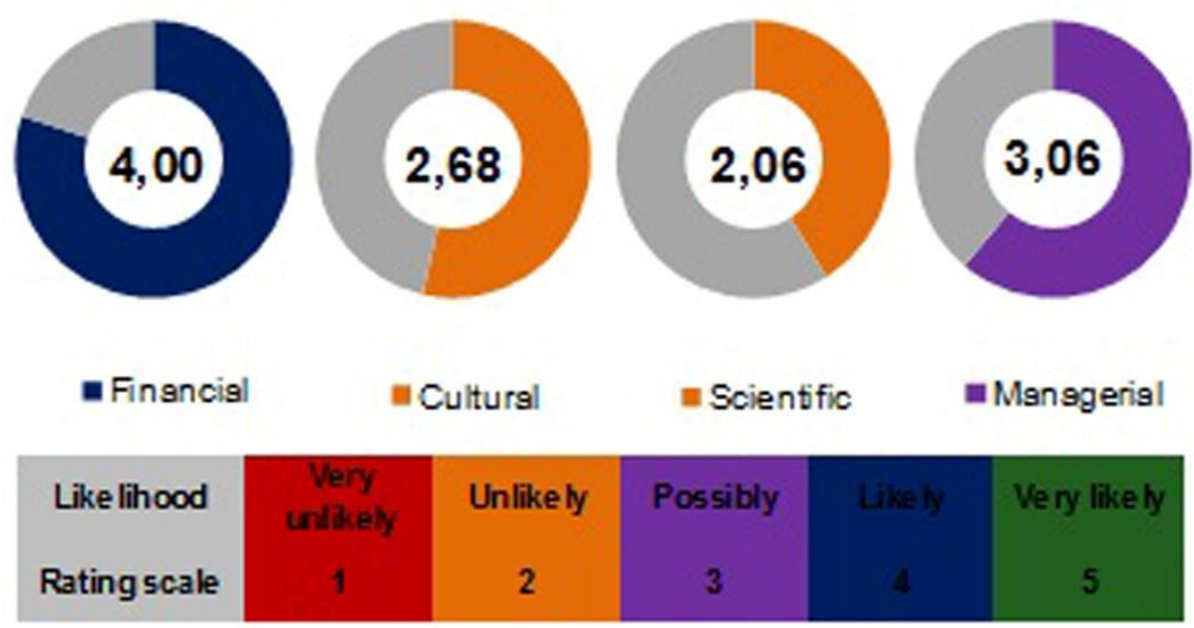

Figure 12. Average results for each Six-sigma challenge

It is evidently seen that money is the main concern that must be addressed when elaborating a strategic implementation plan for Six-sigma. On the other hand, cultural and scientific challenges are not perceived as eminent threats for the program by most of the participants. Finally, changes in the management system seem to be a middle ground topic since technical people tend to think it is not a big concern while managerial personnel believes that it is a likely drawback scenario (Figure 12).

Based on the results previously presented, a SWOT analysis was performed to epitomize the main strengths, weaknesses, opportunities, and threats involved in the application of Six-sigma for Research and Development (Table 2).

According to table 2, for all strengths, there are opportunities. Similarly for each weakness, there is a potential associated threat. For example, time saving could lead to faster product release in the Market, placing the company ahead of its competitors. Correspondently, boost of scientific innovation through a more efficient research process could result in the control of the market with better quality products to fulfill consumers' needs. Allocation of people with the right skills for specific tasks may fasten product development and generate pioneering outcomes. 
Table 2. SWOT analysis of Six-sigma for Research and Development - R\&D in Fast Moving Consumer Goods - FMCG companies (Not found in the core of the survey but suggested in the open-ended question 8 as possible situations to be avoided)

\begin{tabular}{|c|c|c|c|}
\hline Strengths & Weaknesses & Opportunities & Threats \\
\hline Time saving & $\begin{array}{l}\text { Extensive training } \\
\text { required }\end{array}$ & $\begin{array}{l}\text { Faster product } \\
\text { release to market }\end{array}$ & $\begin{array}{l}\text { Financial: high } \\
\text { expenditure during } \\
\text { implementation }\end{array}$ \\
\hline $\begin{array}{c}\text { Better use of } \\
\text { people's knowledge }\end{array}$ & $\begin{array}{c}\text { Managerial } \\
\text { changes required }\end{array}$ & $\begin{array}{l}\text { Groundbreaking } \\
\text { ideas and product } \\
\text { development }\end{array}$ & $\begin{array}{l}\text { Fragmentation of } \\
\text { current management } \\
\text { structure }\end{array}$ \\
\hline Resources saving & Cultural adaptation & $\begin{array}{c}\text { Minimize wastage } \\
\text { of resources }\end{array}$ & $\begin{array}{c}\text { Division of staff } \\
\text { cultural perspective* }\end{array}$ \\
\hline $\begin{array}{l}\text { Boost of scientifc } \\
\text { innovation }\end{array}$ & $\begin{array}{l}\text { Limitation of the } \\
\text { creative process* }\end{array}$ & Market control & $\begin{array}{l}\text { Delay in product } \\
\text { design* }\end{array}$ \\
\hline
\end{tabular}

Extensive training and managerial changes were pointed out as main weaknesses since they could lead to high expenditures and fragmentation of the current management system, respectively. Experienced managerial staff are highly important for ensuring a smooth transition and promoting the success of the Six-sigma program as also described by Easton and Rosenzweig (2012). Limitation of the creative process due to high volume of statistical standards to follow was mentioned in open-ended question 8 as a drawback, but it was not found as a noteworthy impact by the sample majority (Table 2).

\section{Conclusions}

As a general trend, it was seen that the vast majority of the participants perceive Six-sigma methodology as a beneficial change for R\&D in FMCG companies. This was evidenced in the survey since more advantages were pointed out than challenges. Thus greater part of the respondents is inclined to accept the Six-sigma implementation and embrace the necessary changes involved in this process.

It was established by approximately $80 \%$ of the participants that time saving and better people allocation would be the main advantages of Six-sigma for R\&D and these could generate scientific breakthroughs. Resources' saving was also mentioned as a 
probable benefit of Six-sigma. A great support for the implementation was noted once only about $6 \%$ of the sample believes in a possible non-advantageous scenario.

Over $85 \%$ of the survey contributors expressed a concern with the financial challenge during the Six-sigma adoption. This is a strong indication that a well-structured process must be done to avoid unnecessary expenditures. Managerial changes were highlighted as relevant concerns by most of managerial personnel but not by people with technical backgrounds.

In light of the above, Six-sigma was found to be suitable for R\&D in FMCG companies. Its implementation in the research sector could be successful based on the results attained in this study. It is crucial to elaborate a strategic implementation plan, including a risk assessment and detailed budget control. This would result in a smooth transition process and avoid most of the possible challenges previously referred as weaknesses and threats.

\section{References}

Akhilesh, K. B. 2014. R\&D Management. India: Springer. 253 p.

Barone, S.; Lo Franco, E. 2012. Statistical and Managerial Techniques for Six Sigma Methodology: Theory and Application. West Sussex, UK: John Wiley \& Sons. 396 p.

Brun, A. 2011. Critical success factors of Six Sigma implementations in Italian companies. International Journal of Production Economics 131 (1): 158-164. doi:10.1016/j.ijpe.2010.05.008.

Chakravorty, S. S. 2009. Six Sigma programs: An implementation model. International Journal of Production Economics 119 (1): 1-16. doi:10.1016/j.jpe.2009.01.003.

Creveling, C. M. 2002. Six Sigma for Technical Processes: An Overview for R\&D Executives, Technical Leaders and Engineering Managers. NJ, USA: Prentice Hall. $351 \mathrm{p}$.

Dogra, B.; Ghuman, K. 2010. Rural Marketing: Concepts and Practices. New Delhi: Tata McGraw Hill. 350 p.

Easton, G. S.; Rosenzweig, E. D. 2012. The role of experience in six sigma project success: An empirical analysis of improvement projects. Journal of Operations Management 30 (7-8): 481-493. doi: 10.1016/j.jom.2012.08.002

Evans, J.; Lindsay, W. 2014. An Introduction to Six Sigma and Process Improvement. Stamford: Cengage Learning. 344 p.

Hamister, J. W. 2007. Impact of Category Management Practices on Performance of FMCG Supply Chains. 203 p. Ph.D. Thesis, Department of Operation Management and Strategy, The State University of New York at Buffalo, Buffalo, NY, USA. 
Hemant, U. 2010. Six Sigma for Business Excellence: Approach, Tools and Applications. India: Pearson. 379 p.

Hill, C.; Jones, G. 2009. Strategic Management Theory: An Integrated Approach. Mason, USA: Cengage Learning. 528 p.

Ho, Y.-C.; Chang, O.-C.; Wang, W.-B. 2008. An empirical study of key success factors for Six Sigma Green Belt projects at an Asian MRO company. Journal of Air Transport Management 14 (5): 263-269. doi:10.1016/j.jairtraman.2008.05.002.

Jaray, S. 2005. Marketing. Ultimo, N.S.W, Australia: Career FAQs. 151 p.

Joglekar, A. M. 2003. Statistical Methods for Six Sigma: In R\&D and Manufacturing. Canada: John Wiley and Sons. 344 p.

Kwak, Y. H.; Anbari, F. T. 2006. Benefits, obstacles, and future of six sigma approach. Technovation 26 (5-6): 708-715. doi:10.1016/j.technovation.2004.10.003.

McCarty, T.; Bremer, M.; Daniels, L.; Gupta, P. 2004. The Six Sigma Black Belt Handbook. United States: Mcgraw-hill. 589 p.

Nestlé. Annual Report Coorporate Report. 2014. Available in: http://www.nestle.com/aboutus/annual-report. Access: 15 ${ }^{\text {th }}$ Oct., 2015.

P\&G. The Procter \& Gamble Company Annual Report. 2015. Available in: http://www.pginvestor.com/CustomPage/Index?keyGenPage=1073748359. Access: $15^{\text {th }}$ Oct., 2015.

Ryan, T. P. 2013. Sample Size Determination and Power. Canada: John Wiley and Sons. $404 \mathrm{p}$.

Subong, E. A. 2005. Statistics for Research: applications in research, thesis and dissertation writing, and statistical data management using SPSS software. Manila: Rex Bookstore, Inc. 209 p.

Taghizadegan, S. 2010. Essentials of Lean Six Sigma. United States: Elsevier Science. $304 \mathrm{p}$.

Tavana, M. 2014. Analytical Approaches to Strategic Decision-Making: Interdisciplinary Considerations: Interdisciplinary Considerations. United States: IGI Global. 417 p.

Thain, G.; Bradley, J. 2014. FMCG: The Power of Fast-Moving Consumer Goods. Sarasota, Florida: eBook Publishing. 550 p.

Tuckwell, K. J. 2008. Integrated Marketing Communications: Strategic Planning Perspectives. Canada: Pearson Prentice Hall. 440 p.

Unilever. Annual Report and Accounts Overview. Strategic Report. 2014. Available in: https://www.unilever.com/investor-relations/annual-report-and-accounts/annual-reportand-accounts-2015-downloads.html. Access: 15 ${ }^{\text {th }}$ Oct., 2015. 


\section{Appendix 1}

\section{Survey: Six-Sigma implementation for R\&D in FMCG companies.}

You are invited to participate in this MBA dissertation survey which investigates the suitability of Six-sigma tools for R\&D in Fast Moving Consumer Goods (FMCG) companies. This survey is aimed at any person who is or has held any management or technical position in R\&D within a FMCG organization. It will take approximately 5 minutes to complete the questionnaire.

Your participation in this study is completely voluntary and anonymous. There are no foreseeable risks associated with this project. Your survey responses will be strictly confidential and data from this research will be reported only in the MBA dissertation. Thank you very much for your time and support.

\section{Questionnaire}

1) What is the area of your current job position?

- ( ) Management (project manager, director, coordinator, etc.)

- ( ) Technical (scientist, engineer, technician, etc.)

2) How long have you worked for your current organization?

- ( ) 0-3 years

- ( ) 4-6 years

- ( ) 7-10 years

- ( ) More than 10 years

3) How familiar are you with the fundamentals of Six-sigma?

- ( ) Very familiar - I know all its principles and advantages.

- ( ) Moderately familiar - I know a few of its principles and some advantages.

- ( ) Slightly familiar - I have heard of it, but I do not know it very well.

- ( ) Not at all familiar - I have never heard of it.

4) Have you ever used Six-sigma tools at this organization or in previous jobs?

- ( ) Yes, for less than a year.

- ( ) Yes, for more than a year.

- ( ) No, I have never used Six-sigma. 
For the following sections please rate the statements based on your initial reaction so your natural response to the six sigma tools can be correctly measured.

5) Rate each sentence based on your initial reaction:

a) Six-sigma tools can be directly applied to R\&D in FMCG.

( ) Strongly disagree ( ) Disagree ( ) Neutral ( ) Agree ( ) Strongly Agree

b) Six-sigma could significantly improve $R \& D$ and help breakthroughs in FMCG.

( ) Strongly disagree ( ) Disagree ( ) Neutral ( ) Agree ( ) Strongly Agree

c) Some of Six-sigma aspects could be modified to be used in R\&D.

( ) Strongly disagree ( ) Disagree ( ) Neutral ( ) Agree ( ) Strongly Agree

d) Six-sigma would be a step backwards for scientific innovation.

( ) Strongly disagree ( ) Disagree ( ) Neutral ( ) Agree ( ) Strongly Agree

6) Please rate the likelihood of each of those scenarios as a result of the Sixsigma implementation for R\&D in FMCG companies.

a) Time saving - faster progress of research and product development.

( ) Very unlikely ( ) Unlikely ( ) Possibly ( ) Likely ( ) Very Likely

b) Resources saving - reduction of the waste of research resources during the project development.

( ) Very unlikely ( ) Unlikely ( ) Possibly ( ) Likely ( ) Very Likely

c) Better use of people's knowledge - Allocation of the right people for each project task.

( ) Very unlikely ( ) Unlikely ( ) Possibly ( ) Likely ( ) Very Likely

d) Breakthrough innovations - new discoveries due to the more efficient research process.

( ) Very unlikely ( ) Unlikely ( ) Possibly ( ) Likely ( ) Very Likely

e) None - There will not be any advantage.

( ) Very unlikely ( ) Unlikely ( ) Possibly ( ) Likely ( ) Very Likely 
7) Please rate the likelihood of facing each of the following challenges during the Six-sigma implementation for R\&D in FMCG companies.

a) Financial - Money needed to train the team.

( ) Very unlikely ( ) Unlikely ( ) Possibly ( ) Likely ( ) Very Likely

b) Cultural - Get people to adapt to the new research model.

( ) Very unlikely ( ) Unlikely ( ) Possibly ( ) Likely ( ) Very Likely

c) Scientific - Promote breakthrough innovation while following the Six-sigma process.

( ) Very unlikely ( ) Unlikely ( ) Possibly ( ) Likely ( ) Very Likely

d) Managerial - Changes in the management system/structure.

() Very unlikely () Unlikely ( ) Possibly ( ) Likely () Very Likely

8) Please provide possible advantages and/or challenges related to Six-sigma implementation for R\&D which were not previously mentioned in questions 6 and 7.

Thank you for your cooperation! 